\title{
Investigating and Comparing the Situation of Innovation Culture in Lorestan University and Islamic Azad University, Khorramabad Branch
}

\author{
Azita Sattar ${ }^{1, *}$, Saeed Rajaeepour ${ }^{1}$, Ghorbanali Salimi $^{1}$ \& Ahmad Abedi $^{1}$ \\ ${ }^{1}$ Educational Administration , University of Isfahan, Isfahan, Iran \\ *Corresponding author: Educational Administration, University of Isfahan, Isfahan, Iran. \\ E-mail: article.author365@gmail.com
}

Received: August 18, 2014 Accepted: April 25, 2015 Published: May 31, 2015

doi:10.5296/ije.v7i2.7730 URL: http://dx.doi.org/10.5296/ije.v7i2.7730

\begin{abstract}
The main objective of the present study was to investigate and compare the situation of innovation culture in Khorramabad universities according faculty to members' views. The method employed in the study is descriptive and it is a survey research. The population of the study consisted of all full time faculty members of Lorestan University and Islamic Azad University of Khorramabad who were 220 and 148 individuals (totally 368 individuals). The sampling method was proportionate stratified sampling.According to the sample size in this research, 106 individuals from Lorestan University and 67 individuals from Islamic Azad University of Khorramabad were selected as the sample of the study (totally 173 faculty members). For data collection instrument, a researcher-made questionnaire was developed based on five-point Likert scale. The reliability of the questionnaire was calculated using Cronbach's alpha equal as 0.93 and its construct validity was 0.656 which were at acceptable levels. To analyze the data, descriptive statistics (mean and SD) and inferential statistics (one-sample t-test, independent samples t-test, and multivariate variance analysis) were used.

The results indicated that there is a significant difference between innovation culture in Lorestan University and in Islamic Azad University of Khorramabad and it is observed more in Lorestan University.
\end{abstract}

Keywords: innovation culture, innovative intention, organizational learning, competitiveness, innovation implementation, university. 


\section{Introduction}

Nowadays, the system of higher education particularly leading universities are to take steps towards creating new ideas in line with innovation culture by changing their educational system by constructing cultural grounds in academic culture for advancing in the present complicated world.

According to Daft (2001), organizational culture is a set of values, beliefs, perceptions, understanding and ways of thinking which members of an organization share and is a true phenomenon which is given to newcomers to the organization.Williams (1994) knows on organizational culture on the one hand as the connector of elements within an organization and on the other hand, as the distinctive factor of the organization from other ones.Schien (1988) believes that organizational culture is a model of basic assumptions which a certain group has imparted, explored or developed to learn how to fight with the challenges of external compatibility and internal integration.

However, changes in organizational culture appears through influencing individuals' beliefs, values, treatments, and behaviors. It results in optimization and innovation of the organization and influences structural factors in physical context of learning because the success key of organizations particularly universities is utilizing properly innovative and creative capacities and capabilities of personnel particularly faculty members. Changes in academic culture by intention toward innovation results in the survival and development of the organization (Mukerji, 1998).

A strong innovation culture, encountering a dynamic environment, gets compatible with it well. This issue indicate that there is a good relationship among the organization's members. Therefore, the power of innovation, dynamicity and knowledge constructing, is creating ideas from the factors effective on the capability of compatibility of a culture. Academic culture creates a new culture by this timely dynamicity and adds it to its own cultural system and because they are endogenous, they have relations with the society's needs (Attarzadeh, 2006).

Saeedikia (2009) believes that organizational culture influences all aspects of an organization. In fact, regarding the importance of organizational culture particularly the academic culture should be the motivation form innovation and creation of new ideas. From the viewpoints of Commigs\&Worly (2006) efficiency and welfare of a society is created through a group and by creating changes in the culture of organizations specifically academic culture into innovation culture. According to Senge (1990) learning organizations are the motivation of learning innovations which can be transformed in next years; therefore, innovation is one of the main processes of the life of learning organizations, i.e. universities. Kaise(1994)defines innovation as applying modern ideas and presenting a new product and service by presenting a new solution. Jansen et al. (2004) believe that innovation is not merely conscious creation of new and modern ideas, but it covers being exposed to these ideas.

Therefore, regarding the importance of innovation in organizations and that culture has a significant role in creating innovation and idea creation as the culture of every organization, it seems necessary that organizational cultures particularly academic ones should be changed 
into innovation culture which results in promoting the educational performance faculty members as main elements of universities.

Furthermore, according to Allen (1994), unless the culture dominating over an organization is transformed, the creation of new ideas will not come to an end since there is a significant and high correlation between organizational culture and innovation in organizations.

It is possible to increase faculty members' educational performance and create new ideas in line with the welfare of the society and academics by changing in academic culture into innovation culture, and by creating professors' growth and dynamicity in the stage of innovation and idea creation and also producing products such as innovative alumni, increasing the level of articles and knowledge constructing conferences.

\section{Statement of the problem}

In the arena of quick upheavals, universities as learning systems should enjoy dynamicity and flexibility in line with creating new ideas and developing innovation approaches and new products.

Since the power of innovation and the flourish of the degree of accepting new elements in universities are among the factors effective on the capability of compatibility and favorable changes in the academic culture, the importance of creating innovation is obvious because universities add it to their cultural systems and since these factors are endogenous, they are compatible with societies' needs, then academic culture should be powerful for creating transformation. On the other hand, other universities are considered as the main players in national innovation (Mir Sepasi and Afghahi, 2012).

Therefore, the creation of innovation culture and the transformation of educational system at different levels and dimensions of a society and universities seems necessary and they should be considered systematically because in the present dynamic world one cannot fight with changes and transformation with inactivity (SeyyedJavadin, 2000).

On the other hand, although changes in organizational culture is time consuming and the achievement of success in this issue is difficult, the mature cultures can be highly resistant against these changes because they have great consistency and sustainability. In fact, the changes in organizational culture is a dynamic process and the strategies of changes should be consistent with the general planning in the framework of the desired changes (Yazdkhasti and Rajaeepoor, 2009).

All in all, innovation is one of the main processes of surviving educational organizations particularly universities; therefore, academic culture should fundamentally act through encouraging innovation culture. Universities are places in which new thoughts and knowledge, transforming technology and idea creating culture can grow and develop. Since universities have fundamental role in line with innovation, they should consider themselves in the service of development and transcendence (Foyouzat, 2003). Then, paying attention to the creation and development of innovation in universities is necessary. 
From Robbins' viewpoint, innovation means a new belief or idea applied for presenting a product, process or service. In addition, innovation is an aspect of changes.

Therefore, concerning the importance of innovation, the change of academic culture into innovation culture seems necessary. Accordingly, regarding the mentioned issues, the definitions of innovation culture are presented here. Vilano in a research titled as "innovation culture: policies and strategies", takes the technology and historical application of innovation culture as a framework of social or organizational group which understands the channels of technological and economic changes and provides strategies (Wieland, 2006). In addition, according to Dobni (2008), innovation culture is a multi-dimensional concept includingintention to be innovative, the infrastructure to support innovation, operational level behaviorsnecessary to influence a market and value orientation, and the environment to implementinnovation.” (Shahin, 1389).

Regarding the necessity of the change of academic culture into innovation culture, a research titled as "investigating and comparing the situation of innovation culture in Lorestan University and Islamic Azad University, Khorramabad Branch based on Dobni's theory (2008) regarding the components of innovation culture (multi-dimensional concept) which includes innovative tendency, organizational sustainability, organizational learning, creativity and capability, competiveness, valuism and innovation implementation.

\section{Literature Review}

Furest et al. (2007) in a research titled as"Application of the Baldrige Model for Innovation in Higher Education, New Directions for Higher Education" obtained the results that four factors are involved in educational institutes which successfully could manage innovation and changes: the consistent commitment and support of leader and senior managers of organizations, systematic planning methods, cooperative and systematic processes and multi-dimensional and effective communications.

D' Brentani and kleinschmidt (2004) believe that the research indicates that organizational culture particularly innovation promotes the performance of organizations because innovation culture consists of values and features welcoming new ideas (Zhu, 2011).

Dobni (2008), conducted a research titled as" Measuring innovation culture in organization: The development of a generalized innovation culture construct using exploratory Factor analysis", using an exploratory analysis and attained these findings that the criterion of innovation can be indicated using a structure which includes seven factors: innovation thriving, organizational learning, creativity and capability, the tendency of work market, value tendency and implementation environment. These seven factors are applied diagnostically. Finally, he concluded that more measures should be particularly assigned for evaluation criteria of innovation culture because this model presents a practical method for measuring innovation culture and can be applied primarily for creating the level of innovation culture. 
Niknami and Hemmatpoor (2009) in a research titled as "investigating the role of organizational culture in innovation of faculty members of Islamic Azad University for presenting appropriate strategies" indicates that in line with the realization of innovation of faculty members of universities influenced by changing forces, they should change their organizational culture to be able to keep their leading role in the present world.

Attarzadeh (2008) conducted a documentary analysis research titled as "university and innovation, functions and pathology". The findings of the research indicate that the functions of universities, in spite of a relatively long record in Iran, have not properly developed. In evaluating this inefficiency the mixture of two intellectualist and pragmatist approaches in higher education can be effective.

Therefore, the main objective of the study is to investigate and compare the situation of innovation culture in Lorestan University and Islamic Azad University, Khorramabad Branch.

\section{Research Questions}

1. How are the attitudes of professors of Lorestan University towards innovation culture and its components?

2. How are the attitudes of professors of Islamic Azad University towards innovation culture and its components?

3. Is there any significance difference between innovation culture and its components based of university types?

\section{Methodology}

The present study is a descriptive survey research. The method of data collection is survey research using questionnaires. The population of the study includes all full time faculty members of Lorestan University and Islamic Azad University in the academic year 2013-214 in Khorramabad. The number of full time professors of Lorestan University is 220 individuals and the number of those of Islamic Azad University is 148 individuals (totally 368 professors for both universities). The sampling method in the research was proportionate stratified sampling because the size of the classes in the population was different. In addition, to measuring the sample size, Cochrane's formula was used. In this formula, the alpha of 0.05 andthe estimation accuracy was equal as 1 obtained by primary administration on 30 professors of the two universities.

Based on the sample size, in the present study, 173 professors were selected as sample (106 professors form Lorestan University and 67 professors from Islamic Azad University. The instrument of collecting data was the researcher-made questionnaire of university innovation culture. This questionnaire was developed based on the seven component innovation culture of Dobni (2008) and the literature related to innovation culture in a researcher-made form (it 
had 37 closed-ended questions). In this questionnaire, the participants answered the questions based on a five-point scale on Likert scale from 1 strongly disagree to 5 strongly agree. The reliability of the questionnaire was obtained as 0.93 using Cronbach's alpha.

To analyze the data, the descriptive statistics (mean and SD) and inferential statistics (one-sample t-test, independent-samples t-test and multivariate variance analysis) were employed.

\section{Findings}

\section{The first research question}

How are the attitudes of professors of Lorestan University towards innovation culture and its components?

To test this question, the one-sample t-test was used. The results are illustrated in table 1.

Table 1. The results of the one-sample t-test in the total scale of professors' attitudes towards university innovation culture and its components

\begin{tabular}{|c|c|c|c|c|c|c|}
\hline \multirow[t]{2}{*}{ Variable } & \multicolumn{6}{|c|}{$50 \%$} \\
\hline & Mean & $\begin{array}{l}\text { Hypothetical } \\
\text { mean }\end{array}$ & $\begin{array}{l}\text { Mean } \\
\text { Difference }\end{array}$ & $\mathrm{dF}$ & $\mathrm{t}$ & sig \\
\hline $\begin{array}{l}\text { Innovation } \\
\text { culture }\end{array}$ & 71.113 & 111 & $2 / 71$ & 105 & 1.23 & 0.223 \\
\hline $\begin{array}{l}\text { Innovative } \\
\text { intention }\end{array}$ & 04.19 & 18 & 1.04 & 105 & 2. 60 & 0.011 \\
\hline $\begin{array}{l}\text { Organizational } \\
\text { sustainability }\end{array}$ & 20.33 & 12 & 0.77 & 105 & 2. 61 & 0.012 \\
\hline $\begin{array}{l}\text { Organizational } \\
\text { learning }\end{array}$ & 20.33 & 21 & -0.66 & 105 & -1.65 & 0.101 \\
\hline $\begin{array}{l}\text { Creativity and } \\
\text { capability }\end{array}$ & 14. 40 & 15 & -0.59 & 105 & -1.82 & 0.072 \\
\hline Competitiveness & 13. 54 & 12 & 1.54 & 105 & 4. 75 & 0.001 \\
\hline Valuism & 15 & 15 & 0.001 & 105 & 0.0010 & 1 \\
\hline $\begin{array}{l}\text { Innovation } \\
\text { implementation }\end{array}$ & 18. 61 & 18 & 61.0 & 105 & 1.05 & 0.171 \\
\hline
\end{tabular}

The results of one-sample t-test indicate that the mean of components of innovation intention and organizational sustainability of innovation culture of Lorestan University with $95 \%$ of confidence level is significantly higher than the mean index of the questionnaire $(p<0.05)$. But the component competitiveness of university innovation culture with significance level $99 \%$ is significantly higher than the mean index of the questionnaire $(p<0.01)$. Regarding other innovation culture such as organizational learning, creativity and capability, valuism and innovation implementation have significant difference with the cutoff or mean point ( $>0.05)$. 


\section{The second research question}

How are the attitudes of professors of Islamic Azad University towards innovation culture and its components?

To test this question, the one-sample t-test was used. The results are illustrated in table 2.

Table 2. The results of the one-sample t-test in the total scale of professors' attitudes towards university innovation culture and its components

\begin{tabular}{lllllll}
\hline Variable & \multicolumn{7}{c}{$50 \%$} \\
\cline { 2 - 7 } & Mean & \multicolumn{5}{c}{ Mean } \\
\hline Innovation culture & 99.61 & 111 & -11.38 & $0 / 66$ & -3.58 & 0.001 \\
Innovative intention & 17.20 & 18 & -0.79 & 66 & -1.38 & 0.172 \\
Organizational sustainability & 18.08 & 12 & -0.55 & 0.66 & -1.44 & 0.152 \\
Organizational learning & 18.08 & 21 & -2.91 & 0.66 & -4.50 & 0.001 \\
Creativity and capability & 12.89 & 15 & -2.10 & 66 & -4.66 & 0.001 \\
Competitiveness & 11.28 & 12 & -0.71 & 0.66 & -1.50 & 0.142 \\
Valuism & 12.58 & 15 & -2.41 & 66 & -5.32 & 0.001 \\
Innovation implementation & 10.16 & 18 & $89 .-1$ & 66 & $06 .-3$ & 003.0 \\
\hline
\end{tabular}

The results of one-sample t-test indicate that the total mean of the innovation culture of Islamic Azad University, Khorramabad Branch and its components of organizational learning, creativity and capability, valuism and innovation implementation of innovation culture of with $99 \%$ of confidence level is significantly less than the mean index of the questionnaire $(\mathrm{p}<0.01)$. Regarding other components of university innovation culture such as innovative intention, organizational sustainability and competitiveness, no significant difference was not observed ( $\mathrm{p}>0.05)$.

\section{The third research question}

Is there any significance difference between innovation culture and its components based of university types?

To test this question, the one-sample t-test was used. The results are illustrated in table 2.

Table 3. The results obtained from t-test between the professors of Lorestan University and Islamic Azad University in total scale of university innovation culture

\begin{tabular}{|c|c|c|c|c|c|c|c|c|}
\hline \multirow[t]{2}{*}{ Variable } & & \multicolumn{2}{|c|}{$\begin{array}{l}\text { Lorestan } \\
\text { University }\end{array}$} & \multicolumn{2}{|c|}{$\begin{array}{ll}\text { Islamic Azad } \\
\text { University }\end{array}$} & \multirow[t]{2}{*}{$\mathrm{dF}$} & \multirow[t]{2}{*}{$\mathrm{t}$} & \multirow[t]{2}{*}{ Sig } \\
\hline & & Mean & $\mathrm{SD}$ & Mean & SD & & & \\
\hline $\begin{array}{l}\text { The total } \\
\text { university } \\
\text { culture }\end{array}$ & $\begin{array}{l}\text { scale of } \\
\text { innovation }\end{array}$ & 113. 71 & 68.22 & 99.61 & 26. 01 & 171 & 3. 76 & 0.0001 \\
\hline
\end{tabular}

Firstly, Levene's test was administered for variances whose results indicated that the variances of the two groups in university innovation culture are equal because the obtained $\mathrm{p}$ is bigger than 0.05 . Therefore, the null hypothesis which indicate that the variances are equal 
is confirmed. The results of t-test indicted that there is a significant difference between the professors of Lorestan University and Islamic Azad University in the total scale of university innovation culture $(\mathrm{t}(171)=3.76$ and $\mathrm{p}=0.001)$ in such a way that it can be concluded that the value of Lorestan University's innovation culture is bigger than that of Islamic Azad University.

As follows, to test this question whether there is any significant difference between the scales of university innovation culture of Lorestan University and Islamic Azad University, MANOVA was administered. The results are indicated in table 4.

Table 4. The results of multivariate variance analysis test based on university types in sub-scales of university innovation culture

\begin{tabular}{|c|c|c|c|c|c|c|}
\hline Resource & Dependent variable & $\begin{array}{l}\text { Sum of } \\
\text { squares }\end{array}$ & $\mathrm{df}$ & $\begin{array}{l}\text { Mean of } \\
\text { squares }\end{array}$ & F value & Significance \\
\hline \multirow{7}{*}{$\begin{array}{l}\text { University } \\
\text { type }\end{array}$} & Innovative intention & 138.71 & 1 & 138.71 & 7.33 & 0.007 \\
\hline & $\begin{array}{l}\text { Organizational } \\
\text { sustainability }\end{array}$ & 72. 16 & 1 & 72.16 & 7. 60 & 0.006 \\
\hline & $\begin{array}{l}\text { Organizational } \\
\text { learning }\end{array}$ & 206. 10 & 1 & 206. 10 & 9.62 & 0.002 \\
\hline & $\begin{array}{l}\text { Creativity and } \\
\text { capability }\end{array}$ & 93. 62 & 1 & 93. 62 & 7. 69 & 0.006 \\
\hline & Competitiveness & 210.34 & 1 & 210.34 & 16. 51 & 0.001 \\
\hline & Valuism & 240 & 1 & 240 & 19. 70 & 0.001 \\
\hline & $\begin{array}{l}\text { Innovation } \\
\text { implementation }\end{array}$ & 37.258 & 1 & 258. 37 & 11.22 & 0.001 \\
\hline
\end{tabular}

The results of Pillai's Trace Test equal as 0.08 is significant $(F(7.276)=3.43$ and $p=0.002)$ indicate that the hypothesis of similarity of the means of population based on dependent variable for Lorestan University and Islamic Azad University cab be rejected. The square of the multivariate eta equals 0.08 , i.e. 8 percent of the multivariate variances of dependent variables are related to the factor of university types. The results of MANOVA indicate that there is a significant difference between the professors of Lorestan University and those of Islamic Azad University in terms of all components of university innovation culture; therefore, it can be concluded that university innovation culture in Lorestan University is more than in Islamic Azad University.

\section{Suggestions}

Regarding the results of the research the following suggestions are presented:

Regarding the role of universities as learning systems in line with creating new ideas and applying them and also regarding the changes in organizations and by identifying effective 
factors of innovation, by creating a strong culture, we should move towards changing academic culture into innovation culture.

Furthermore, to produce ideas and implementation in universities, first of all this opportunity should be provided for evaluating academics particularly faculty members in order that by creating an idea, product or service, they perform the new procedure which is valuable and new. Therefore, by applying that idea and products, the favorable changes in line with innovation and knowledge construction of professors can be possible.

Academic culture should create values which support creative and innovative behaviors. In fact the existence of supportive culture in universities for innovation promotion and development is a vital issue. By creating motivation in personnel particularly professors, values such as flexibility, freedom of action, cooperation, team work, innovation and creativity can be promoted.

\section{References}

Allen, T. (1994). People and technology transfer. International Center for Research of Management of Technology.

Attarzadeh, M. (2008). University and innovation, functions and pathology. Islamic Azad University Journal. $12^{\text {th }}$ year, no. 4. Pp. 23-37.

Comminker, T, J., \& Christopher, W. (2006). Transformation and development.In organiztions. K. Bararpoor, K. Tehran: Andishe Sabz Publication.

Daft, R. D. (2001). Organizational theory and design. In A. Parsian and S. M. Arabi (Trans.), Tehran: Cultural Research Institute.

Dobni, C.B. (2008). The DNA of innovation. Journal of Business Strategy, 29(2), 43-50. http://dx.doi.org/10.1108/02756660810858143

Furst-Bowe, Julie A., \& Baucer, Roy A. (2007). Application of the Baldrige Model for Innovation in Higher Education. New Directions For Higher Education, 137, 5-14. http://dx.doi.org/10.1002/he.242

Fyouzat, Y. (2003). The role of universities in national development. Tehran: Arasbaran Publication.

Janssen, O., van devliert, E., \& Wesr, M. (2004). The bright and Dark side of individual and group innovation: a special issue introduction. Journal of Organization Behavior, 25(2), 129-145. http://dx.doi.org/10.1002/job.242

Kaser. (1994). You and creativity. Aluminum News, 25(3), 4.

Mirsepasi, N., \& Afghahi, B. (2012). Comparing the analysis of organizational intelligence in higher education. Educational Research Journal, 65(18), 81-87. 
Mukerji, A., \& Mukerji, V. (2000). The organization of structures in future. A. Asadi (Trans.). Administrative transformation. Tehran: Management and Planning Organization.

Niknami, M., \& Hemmatpoor, M. (2009). Investigating the role of organizational culture in innovation of the faculty members in Islamic Azad University for presenting proper strategies. Journal of Management and Work, 80, 103-114.

Robbins, S. (2010). Organizational behavior. In A. Parsian and S. M. Arabi (Trans.). Tehran: Cultural Research Institute.

Saeedikia, M. (2009). The motivating innovation culture in organizations. Tadbir Journal. Institute for Humanities and Cultural Studies. Comprehensive Portal of Human Sciences. No. 209.

Schein, H.E. (1988). "Innovative cultures and adoptive organizations working. Paper Sloan school of management Massachusetts Institute of Technology. Cambridge. MA.

Senge. P. (1990). The fifth Discipline: the Art and practice of the learning organization. New York: Doubleday.

SeyyedJavadin, R. (2000). Technology, educational innovation a changes. Tehran: Education Institute.

Shahin, A., \& SadeghBeig, A. (2010). Innovation management. Isfahan. Jihad Daneshgahi Publication.

Wieland, T. (2006). Innovation culture, technology policy and the use of the history. International proact conference innovation pressure 15- 17 march, Munchen, Germany.

Williams, A. (1994). The Hand book of Human Resource management. London: Brains towers Publishing.

Yazdkhasti, A., \& Rajaeepoor, S. (2009). Organizational culture and comprehensive quality management in higher education. Isfahan: Kankash Publication.

Zhu,C. (2011). Organizational culture and International Innovation in higher education. Educational Management Administration \& leader ship.

\section{Copyright Disclaimer}

Copyright for this article is retained by the author(s), with first publication rights granted to the journal.

This is an open-access article distributed under the terms and conditions of the Creative Commons Attribution license (http://creativecommons.org/licenses/by/3.0/). 